\section{Jurnal Hukum Volkgeist \\ Volume 5 Issue 1, Desember 2020 \\ P-ISSN : 2528-360X, E-ISSN : 2621-6159}

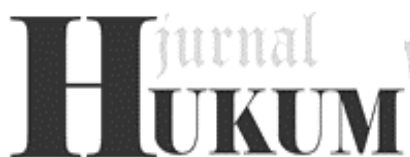

Mimbar Pendidikan Hukum Nasional

\title{
The effectiveness of the implementation of diversion on children who conflict with the law at the level of the state court in gorontalo province
}

\author{
Muhammad Rizal Lampatta ${ }^{1}$, Herlina Sulaiman ${ }^{2}$
}

\begin{abstract}
Diversion is a step or legal remedy aimed specifically at children who are in conflict with the law. As perpetrators of criminal acts, children need to be treated differently from adults. This is due to the psychological condition of children who are considered unable to accept criminal sanctions. Even children who have committed criminal acts, Act No. 11 of 2012 on the Criminal Justice System Children continue to provide collateral in the form of diversion efforts so that children avoid criminal prosecution. Diversion is carried out at the police, attorney and court levels. Not all cases of child offenders who enter the PN level can be diversified because there are already rules in the SPPA Law, Perma No. 4 of 2014 and PP. 65 of 2015. Likewise in the implementation of diversion at the District Court level in Gorontalo Province, some were successful and some were not. This study aims to determine the effectiveness of the implementation of diversion to child offenders at court level in Gorontalo Province. As well as to find out the obstacles in the implementation of diversion against child offenders at the District Court level in Gorontalo Province.
\end{abstract}

Keyword : Diversion, Children, Conflict

\author{
Author's Information: \\ ${ }^{1}$ Law Department, \\ Universitas Ichsan Gorontalo, \\ Indonesia \\ (Rlampatta@gmail.com) \\ ${ }^{2}$ Law Department, \\ Universitas Ichsan Gorontalo, \\ Indonesia \\ (herlina.sulaiman.hs@gmail.com) \\ Article's Information: \\ DOI: \\ https://doi.org/10.35326/volkgeist.v5i1.897
}

\section{Introduction}

Child protection is a must for the State in protecting and developing human beings completely. In article 1 point 2 of Law Number 23 of 2002 stipulates that child protection is all activities to guarantee and protect children and their rights so that they can live, grow, develop and participate, optimally in accordance with human dignity, and receive protection from violence and discrimination.(Hambali, 2019)

Children are the mandate and gifts of God Almighty, who are inherent in their dignity as a whole human being. Furthermore, it is said that children are the buds, potential, and young generation who are the successors of the ideals of the nation's struggle, have a strategic role and have special characteristics and characteristics that ensure the continuity of the existence of the nation and the State in the future. (Harefa, 2019)

When children become perpetrators of criminal acts, it is certainly imperative for law enforcers to maintain that the implementation of the judicial process does not violate children's human rights which are protected by law. The form of legal protection for children who are in conflict with the law or especially as perpetrators of a criminal act is the application of the concept of diversion which is derived from the concept of restorative justice.

One of the systems built in the current SPPA Law is the concept of restorative justice as contained in Article 5 of the SPPA Law which is contained in the diversion process against children of criminal offenders. 
UNICEF provides another definition of diversion, namely: Diversion means the conditional channeling of children in conflict with the law away from judicial proceedings through the development and implementation of procedures, structures and programs that enable many - possibly most - to be dealt with by nonjudicial bodies , thereby avoiding the negative effects of formal judicial proceedings and a criminal record. ( www.unicef.org ).

The concept of diversion is not only implemented at the level of investigation, but also at the court level so that efforts to prevent children from being sentenced to punishment. The meaning of diversion can be found in Law Number 11 of 2012 concerning the Juvenile Criminal Justice System Article 1 paragraph (7) which reads: "Diversion is the transfer of settlement of cases of children from the criminal justice process to the out of court process"

From the meaning of diversion based on Law Number 11 of 2012 concerning the Juvenile Criminal Justice System, it can be seen that in the settlement of juvenile criminal cases, efforts are made to be resolved out of court. This has a good purpose for the mental personality of the child who is involved in legal problems, because at the age of classification of the child, the child is developing and growing to become a good person, so that if criminal justice is carried out for the child, it is possible to psychologically disturb the child and result in disturbances in growth.

In this research, there will be a more in-depth study regarding the implementation of diversion so that children feel that they are not freed or privileged by law, besides that in the implementation of diversion it is necessary to pay attention to aspects of legal awareness and education for children. It should be noted that diversion is punishment by prioritizing children's human rights so that if it is misunderstood by the child it can have a bad impact where the results of diversion will not provide an improved attitude that can give birth to new delinquency because children only understand that diversion is one way to be freed from legal proceedings. .

District Courts throughout Gorontalo have handled various types of criminal offenses that have been committed by children. Of course, before the trial takes place further, the district court judge will seek diversion so that these legal issues can be resolved more in a family atmosphere.

\section{Method}

In the research that the researchers will do, use empirical legal research methods. Empirical legal research is one type of legal research that analyzes and studies legal work in society.

\section{Result and Discussion}

\subsection{The Effectiveness of the Implementation of Diversion for Children in Conflict with the Law at the District Court Level in Gorontalo Province}

The process of punishment given to children through the formal criminal justice system by putting children in prison does not succeed in deterring children and becoming a better person to support their growth and development process. (Sari, 2013)

Galles Richard $\mathbf{J}$ suggests that crimes committed by children occur due to a combination of various factors. Namely as follows: 
a. Inheritance of intergenerational violence ( intergenerational transmission of violanee ) many children learn violent behavior from their parents and when they grow up they commit violence against their children.

b. Social stress ( social stress ) Stress caused by various social conditions increases the risk of violence caused by children.

c. Social isolation and community involvement under the parents and substitute parents who commit violence against children tend to be socially isolated ..

d. Family Structure . Certain types of families have an increased risk of committing acts of violence and neglect against children.(Arliman, 2015)

Some of the factors mentioned above can at least illustrate several factors that can affect children's development in a negative direction. Even though children are not only seen as perpetrators of crimes but also as human beings who need special protection.

Developments sisterm juvenile justice certainly suffered a lot of criticism in which there is an understanding that the formal criminal justice process tends to create stigmatization of children, and even become a factor kriminogen recurrence of delinquency of children. Allowing children to face elements in formal criminal justice, such as the unprofessional culture of law enforcement officers and low sensitivity to child protection, is tantamount to criminalizing children. (Harefa, 2019)

The understanding as stated above can of course be a consideration in improving the judicial system in the future whether the current system is capable of facing challenges to restore the younger generation who committed criminal acts in a better direction .

The implementation of diversion is motivated by the desire to avoid negative effects, especially on the psyche and development of children that have the potential to occur if the completion of the criminal process is carried out through the criminal justice system. (Priamsari, 2018)

If it is examined more deeply that the implementation of diversion has the objectives stipulated in the SPPA Law that: by implementing diversion, peace can be achieved between the victim and the child; the implementation of diversion is a way of resolving cases of children outside the judicial process; can provide opportunities for children not to be deprived of their liberty to provide encouragement and space for participation to the community ; instilling a sense of responsibility to children.

As for child delinquency that can be considered, it is seen from the category of delinquency or crime. Crime can be divided into three categories, namely mild, moderate and severe. In general, children who commit minor delinquency should be diversified as much as possible. For moderate crime / delinquency, there are considerations for diversion. For serious crimes, diversion is not an option. (Browning, 2019)

However, according to the author, the more basic essence of the implementation of diversion is that children feel that they are not liberated or privileged by law, besides that in the implementation of diversion it is necessary to pay attention to aspects of legal awareness and education for children. It should be noted that diversion is a form of punishment by prioritizing children's human rights and not an opportunity to get parole for their mistakes so that if they are misunderstood by the child it can have a bad impact where the results of diversion will not provide an improvement in attitudes that can give 
birth to new delinquency because of the child. only understand that diversion is one way to be freed from a lawsuit.

According to District Court Judge Marisa Moh. Mr. Fahrul Anam (interview in August 2020) that:

"As an implementation of restorative justice, there is diversion so that children are not contaminated with the prison atmosphere and victims can recover their losses, besides that the perpetrator can realize without retaliation. Diversion as a child's right that must be protected. The success of diversion cannot be forced because it depends on the victim and the perpetrator.

Consideration does diversion by the court based on the philosophy of the juvenile criminal justice system is supposed to protect and rehabilitate (protection and rehabilitation ) of children as perpetrators tindakpidana. Diversion is also carried out as an effort to prevent a child offender from becoming an adult criminal. This child prevention effort has led law enforcement officials to take discretionary powers. (Ina Helian, 2018)

Then Mrs. Justice Yosie Anastasia Simanjuntak, SH Judge PN Tilamuta (interview July 2020) gave an opinion that:

"If you look at current legal developments, this diversion is a mandate of restorative justice, which must restore the situation to its original state. Not with this diversion it becomes an opportunity to release children from responsibility, but diversion in court where in PP and Perma given space / alternatives, but Not a form of giving punishment to children, giving responsibility such as returning to parents or entrusting it to the LPKS, there are many considerations for child facilitators or judges in trying to reach an agreement between the victim and the perpetrator because there is the role of community advisers, social workers and other parties.

Apart from that, we are obliged to consider the results of the Community Counselor's research because from the research results we can determine what is best for the child. "

Based on the exposure of judges is very important diversion from the imprisoning children because it is very relevant to the issues of development and child psychology ( Child development and psychology ). If a child is faced with the law, if he is directly confronted with a formal legal process, it is considered that it will harm the child's development. Some elements that are considered as negative impacts are:

- Child stigmatization and labeling

- Much of the nature of the existing criminal system is retributive rather than restorative .

- The many stages of using the detention system in the pre- trial process.(Parker, 2020)

In this study, the implementation of diversion which is examined for its effectiveness is the implementation of the diversion concept in four (4) District Courts in Gorontalo Province. The four district courts are the Gorontalo District Court, the Limboto District Court , the Tilamuta District Court and the Marisa District Court

From the results of research data obtained in the 4 courts above, it can be seen that: 


\section{Gorontalo District Court}

Of the 17 cases of children in conflict with the law that have been submitted to the Gorontalo District Court since 2017, 3 cases have been requested for diversion from the court because these cases have been resolved at the Police level, namely in register No. B / 17 / III / 2019 / Reskrim, No. 02 / SKD / XII / 2018 / Then and B / 09 / II / 2018 / LL / Res GTlo Kota. Then 3 cases, namely: 1 case successfully diversified at court level with case number 4 / Pid.Sus-Child / 2020 / PN Gto , and 2 cases that were unsuccessful, namely case number 13 / Pid.Sus-Child / 2019 / PN Gto and 4 / Pid.Sus Anak / 2019 / PN Gto . While the rest were not carried out diversion because the criminal charges were over 7 years.

At the time of this research, the case number 4 / Pid.SusAnak / 2020 / PN Gto was a case that had recently been successfully diversified. According to the Judge of the Gorontalo District Court, Ottow Siagian, SH, said:

"Regarding the case of the latter in the diversion is a case of abuse of the level of investigation and prosecution did not succeed in versioned, but with the efforts made by the PN Gorontalo, the case reached the agreement set forth in the Stipulation of diversion No.1 / Pen.Div / 2020 / PN .Gto September 10, 2020, which consists of 6 Articles"

\section{Limboto District Court}

In the Limboto District Court, based on the explanation from the Legal Department, it was stated that from 2019 to 2020 there were no cases that could be diversified. So out of 20 cases there are only 2 cases that can be diversified .

\section{The Tilamuta District Court}

In the Tilamuta District Court, on average, cases that enter cannot be diversified because the indictment is over 7 years old or does not meet the requirements for diversion. Based on the author's interview with the Tilamuta District Court Judge, Mr. Rastra Dhika Irdiansyah, S.Kom., SH, MH (July 2020) he said that:

\footnotetext{
"We as child judges or diversion facilitators cannot carry out diversion in every case of a child who is admitted to the Tilamuta District Court because basically the indictment of the Public Prosecutor against ABH has exceeded 7 years, even though there are rules in Perma No. 4 of 2014 regarding the permissibility of diversion. in cases of children who are over 7 years of age but there is no choice of one of the charges under 7 years (alternative, cumulative or subsidary charges) in some cases that are admitted to the Tilamuta District Court"
}

\section{Marisa District Court}

At the district court Marisa based on the data above it can be seen that the PN Marisa since the year 2017 up to 2020 there are 13 cases of criminal offenses committed by children. 5 cases were successfully diversified in case No. 8 / Pid.Sus-Anak / 2019 / PN Mar, No. 4 / Pid.Sus-Anak / 2019 / PN MAR, No. 5 / Pid.Sus-Anak / 2019 / PN Mar , No. 3 / Pid.Sus-Anak / 2019 / PN MAR, and No. 1 / Pid.Sus -Children / 2019 / PN . MAR . then 2 unsuccessful cases were diversified to case No. 7 / Pid.Sus-Anak / 2019 / PN Mar and No. 2 / Pid.Sus -Children / 2019 / PN Mar .

. Based on the author's interview with the Junior Criminal Registrar, Mr. Yunus Ahmad, SH (interview in September 2020) that:

"Of the cases that were submitted to the Marisa District Court, where the perpetrator was a child, a total of 13 cases out of the total were 5 cases that were successfully diversified, 
then 2 cases that were not successfully diversified and the remaining 6 cases were not obliged to be diversified. Diversion is not mandatory, meaning in that case because the sentence is more than 7 years. "

Based on the overall data on criminal acts committed by children who entered from 2017 to 2020 at the district court level in Gorontalo Province, it can be seen as many as:

1. 11 Child cases were successfully diverted (3 Cases of Court Decisions because the Cases have been resolved at the Police level)

2. 4 The case of not being successfully diversified

3. 44 cases were not diversified because the sentence exceeded 7 years

The large number of cases of children who cannot be diversified because of the threat of a sentence of more than 7 years, of course, has closed the opportunity for children to get this opportunity.

If you look at the SPPA Law that applies in general to each level of diversion, it will certainly make it a little difficult for the Judge / facilitator to be diversified at the court level so that with the existence of Government Regulation No. 65 of 2015 and Perma No. 4 of 2014 make it easier for the District Courts to pursue Diversion. The judges at the District Court felt the birth of these two regulations. On average, the judges that the researchers met said that they were greatly helped by the existence of these two regulations

Even with the existence of Perma No. 4 of 2014, the diversion process becomes more efficient for the District Court, this is in line with what was said by Judge PN Tilamuta, Mr. Rastra Dhika Irdiansyah, S.Kom., SH, MH (July 2020) that

\footnotetext{
" We are in the effort to implement diversion, although now at PN Tilamuta there are no cases being diversified, at this time we will still combine the three regulations, namely the SPPA, Perma and PP Laws. Moreover, Perma No. 4 of 2014 Specifically regulates technical matters at the court level. With these three regulations, there are more technical and detailed guidelines on the procedures to be followed "
}

Based on the above interview, the District Court has its own technical guidelines so that even though the investigation and prosecution stage cannot be carried out, diversion can be carried out at the Court level as regulated in Article 3 Perma No. 4 of 2014 is written that:

"The judge is obliged to seek diversion in the case that a child is charged with committing a criminal act which is punishable by imprisonment of less than 7 (seven) years and is also charged with a criminal offense punishable by imprisonment of 7 (seven) years or more in the form of a subsidiarity indictment, an alternative. , cumulative, or combination (combined)"

Thus the Perma regulation provides an explanation that in the case of a child in which there are charges of subsidence, cumulative or combination where one of the charges has one of the charges under 7 years of age, diversion can be carried out. This is what can be used as a guideline for PN judges to oblige diversion.

For example, as stated by Judge Muhlis Kadafi, SH at PN Limboto (August 2020) in his experience when implementing diversion in Aceh that; 


\begin{abstract}
"Based on my experience before being assigned to PN Limboto, at that time I did a diversion from my assignment. In Aceh in 2017, there were cases of narcotics which investigators and prosecutors did not attempt to diversify. But I said I could

diversion. Perma 4 Tahun 2014 can only be used at the Court level because one of the charges is under 7 years. At that time in that case I considered the victim to be represented by the (state) prosecutor, I asked the prosecutor whether or not to be diverted, the prosecutor said he accepted. At that time the charges for the Narcotics Law, Articles 112, 114 and 127 (maximum 4 years). With the existence of article 127, there is a basis for diversion and finally success.
\end{abstract}

The opinion above is in line with the words of Mr. Judge Ottow Siagian, SH, Judge of the Gorontalo District Court, he said:

"If there is a case that goes to the district court that uses the charges of subsidence, cumulative or combination, it will be seen whether any of the charges contain criminal offenses under 7 years. For example, in the criminal act of theft the charges are articles 362, 363 and 365 it will be known that one of them is a crime with a low penalty of under 7 years. "

From the results of research in the field of implementation stages of diversion at the court level using Perma No. 4 of 2014 which Article 4 and Article 5 of the Perma have been detailed carefully and clearly. The stage of implementing diversion starts from the preparation where after the issuance of an order from the Chief Justice to handle a diversion case, the judge will determine the day, date, time and place of the diversion deliberation. In the determination of the judge, there was an order to the public prosecutor who delegated the case to present parties involved in the implementation of diversion such as BAPAS, Professional Social Workers, Victims and their families / guardians, children of perpetrators and their families, representatives of the community and parties deemed necessary to be involved. in the implementation of the diversion.

In the success of the diversion process the roles of Bapas and Peksos were very large. The function of Bapas in the SPPA Law is precisely Article 84 . D ari second explanation is that article explaining that Bapas shall conduct the supervision program that was created by the implementation of the Community Supervisor then implemented by LPAS and LPKA

For this reason, BAPAS and social workers have the most active role in researching the lives of children in the community and their families, because in the SPPA Law, if there is no examination from BAPAS, the diversion cannot be carried out, so according to the research team this aspect of education and control lies also in the agreement on when the diversion was implemented

The role of Bapas is very crucial because in addition to playing a role during the implementation of the diversion process it also plays an important role after successful diversion which must prepare several coaching programs such as for child offenders such as religious guidance, intellectual and behavioral guidance, skills development, independence development, professional development and coaching. physical and spiritual health. The various kinds of training must be in accordance with the needs and age of the child. In carrying out its duties, BAPAS must also coordinate intensely with the LPKS Leaders. The LPKS leadership must periodically submit a written report to Bapas regarding the development of the child during the education, coaching, and mentoring program at the LPKS

But like a currency, every law must have a loophole for other people to take advantage of it, the author said because there were several cases where children were used to commit criminal acts because children had the privilege of being carried out by 
diversion, but according to Mr. Ottow Siagian, Judge of PN Gorontalo said that we should not only look at the aspect of the gaps, but we must also look at the positive aspects because even though there are gaps that are used by certain people but later with the gaps, one day the SPPA Law will certainly be changed for the better.

The effectiveness of diversion is not only measured by the success of the implementation of deliberation so as to give birth to a diversion agreement but is measured until the agreement is fulfilled whether the parties, especially the children of the perpetrator, have succeeded in fulfilling the agreement set out in the agreement. If not, the agreement is considered unsuccessful. The specified time period is 3 months and can be extended for another 3 months as stated in PP 65 of 2015 Article 64 .

The intensive supervision provided by the parties involved in the diversion agreement can provide moral deepening and good attitudes to the perpetrator so that they do not repeat their actions, especially the types of punishment that can be given can be in the form of community service as regulated in Article 6 Paragraph (3) letter d, PP Number 65 of 2015 .

This community service sanction can be applied, such as the experience made by PN Limboto, Muhlis Kadafi, SH in an interview session (August 2020) who revealed:

\begin{abstract}
"As I did before in Aceh, I directed the perpetrator to be educated at Islamic boarding schools so that they could get a good religious education for several months. So to be more optimal, after an agreement between the perpetrator and the victim can be given social punishment, such as cleaning the mosque if he is Muslim, chanting the call to prayer at several times (dawn, Dzuhur, Asr, Maghrib or Isya) accompanied by a report from the imam or the mosque. . So it is the type of social punishment or the result of an agreement that is directed into education for the perpetrator so that he is aware of his actions. "
\end{abstract}

If in every case committed by a child applies restorative justice, it can indirectly reduce children detained in detention and prisons, fewer cases go to court, reduce the number of prisoners in the institution and also reduce the state budget. If all perpetrators of criminal acts in this case are included in petty crimes committed by a child, and then inserted into a correctional institution very has a use value because it adversely affected the child itself ( Yuliana Ratnadewi. 2018)

\title{
3.2. Factors That Become Obstacles In The Diversion Determination Process
}

According to Peter C. Kratcoski in Hengky Kurniawan, there are three types of concepts for implementing diversion programs, namely:

1. Execution of social control

2. Social services by the community to the perpetrators ( social service orientation ),

3. Towards the process of restorative justice or negotiation ( blanced or restorative justice orientation ).(Hambali, 2019)

Diversion as an obligatory process to apply the concept of restorative justice certainly gets many opinions. There are those who argue that diversion can prevent children from being punished with deprivation of freedom. However, there is an opinion that the implementation of diversion is only a mandatory procedure that must be followed by law enforcers, victims and their families, perpetrators and their families, BAPAS and several related parties. So that the aspect of deepening awareness and the aspect of providing moral education to the perpetrator is not being paid attention to which causes the perpetrator to repeat his criminal act to other victims. 
This assumption must of course be broken in order to maintain the spirit of the implementation of diversion which is the aim of law enforcement in terms of providing justice, certainty and benefits in the restorative justice space. The way to break this assumption according to the research team is not easy, it must also be accompanied by the seriousness of law enforcers in providing maximum diversion results in the hope that the child perpetrators of a crime will get legal awareness to be aware and deterred without having to experience the punishment of freedom restriction in the Penitentiary.

Justice restorative not merely implementing the decisions about who won and who lost in the criminal justice system that is hostile / resistance (adversarial system ). In its concept, the restorative justice process seeks a facility for dialogue between all parties affected by crime including victims, perpetrators, their supporters, and society as a whole. This involves a process in which all parties at risk in a particular crime collectively seek to resolve collectively how to deal with the aftermath of a crime and its future implications.(Bustamam, 2020)

$\mathrm{M}$ ccording to the research team is not so impossible later in the concept of ius contituendum (legally The idealized) model of diversion can be modified that there might be a change in the limit of seven years to more than seven years with the qualification of the offenses anything that can done diversion. This is in line with what Judge Tilamuta said during the interview .

According to Mr. Judge PN Limboto, Moh. Fahrul Anam, SH, (August 2020) that:

"In my opinion, maybe one day the SPPA Law should be modified by legislators in the Legislative to make changes to the model of punishment for children, especially in the form of diversion, where all child crimes can be diversified or can be modified in accordance with legal developments. ".

In the implementation of diversion in 4 District Courts in Gorontalo Province, there are several obstacles that the authors can describe, namely:

1. In the implementation of diversion, an agreement is sometimes difficult to obtain because there is still an assumption that giving punishment to the perpetrator can satisfy the heart of the victim or the victim's parents. According to Judge Ottow Siagian SH, Judge of Gorontalo District Court :

\footnotetext{
"Based on my experience, at the time of diversion implementation we as diversion facilitators gathered all the existing parties such as BAPAS, Social Workers, parents of victims and perpetrators. What I saw during the implementation process "sometimes" the parents did not agree to peace even though their children agreed. This barrier on the part of the parents is a barrier to achieving diversion ".
}

2. A diversion agreement was not reached because the victim or the perpetrator did not have a common ground in determining the amount of compensation.

3. The absence of Bapas at the District Level and LPKS are only in Gorontalo City and

\section{Pohuwato Regency}

4. Barriers commonly found in the process of establishing the diversion of children in conflict with the law, usually Reports Community Supervisor little late, and the hose was a difference of opinion of social workers associated with the involvement of social workers in penaganan children in conflict with the law because it is not involved. Meanwhile, social workers from BAPAS are already there to represent other social workers. 
5. The rules in Perma No. 4/2014 and PP No. 65 of 2015 in which the child commits a crime under 7 years or over 7 years in accordance with Article 3 Perma No. 4 of 2014 will be diversified, in contrast to PP. 65 of 2015 only regulates criminal offenses under 7 years. Apart from that, the Perma also does not regulate whether the crime is repetition or not, but in PP. 65 restricts not repetition of the crime.

6. Community participation that still lacks supervision of children, especially children who live in the surrounding environment if the child is involved in a criminal act.

7. The need for co-operation between the Father s with doctor / psychiatrist.

According to Mr. Rastra Dhika Irdiansyah, S.Kom., SH, MH Hakim PN Tilamuta (July 2020) that

\begin{abstract}
"We as child facilitators or judges cannot know for sure how the psychological condition of the child or the environment in which this child lives. The judge knows from the BAPAS and Peksos reports that BAPAS or Peksos should collaborate with psychologists or doctors. So far, BAPAS / Peksos have only reported good environmental conditions, good families, but never give consideration to the psychological condition of children personally. That is why in the regions, BAPAS, LPKS and LPAS must be complete. As well as establishing cooperation with psychologists or doctors"
\end{abstract}

In its implementation, although diversion is intended to protect children from stigmatization and pressure from the judicial process, if diversion is carried out carelessly and is not followed by actions of guidance and recovery, it will even threaten the future of children who are in conflict with the law.

\title{
4. Conclusion
}

The effectiveness of Diversion Implementation for Children in Conflict with the Law at the District Court Level in Gorontalo Province based on the number of cases submitted, it can be categorized as quite effective because of the 15 cases that were diversified, 11 cases were successful and 5 cases were not successfully diversified .

In the implementation of diversion in 4 District Courts in Gorontalo Province, there are several obstacles that the authors can describe, namely:

- There is still a stigma that punishing the perpetrator satisfies the victim's family

- A diversion agreement was not reached because the victim or the perpetrator did not have a common ground in determining the amount of compensation

- The absence of Bapas at the District Level and LPKS are only in Gorontalo City and Pohuwato Regency

- The Community Advisor's report is a little late

- The rules in Perma and PP regarding Diversi are not synchronized

- Community participation is still lacking.

- The need for cooperation between you and your doctor / psychiatrist.

\section{References}

Arliman, L. (2015). Komnas HAM and Child Protection for Criminal Offenders. 
Yogyakarta: Deepublish.

Browning, Z. (2019). A Comparative Analysis: Legal and Historical Analysis of Protecting Indigenous Cultural Rights Involving Land Disputes in Japan, New Zealand, and Hawai'i. Washington International Law Journal, 28(1), 207.

Bustamam, R. P. and A. (2020). Mainstreaming Diversion of Children in Aceh: Between Ideals and Reality. Journal of Gender Equality : International Journal of Child and Gender Studies, 6(1).

Hambali, A. R. (2019). Implementation of Diversion for Children Facing the Law in the Criminal Justice System. Legal Policy Scientific, 13(1).

Harefa, B. (2019). Kapita Selekta Legal Protection for Children. Yogyakarta: Deepublish.

Ina Helian, E. H. M. (2018). Diversion Effectiveness Based on Law No. 11 of 20112 Concerning the Child Criminal Justice System Against the Juvenile Criminal Justice System. Proceedings of the 4th National Seminar on Scholars of 2018 Book II.

Parker, L. (2020). Becoming Someone. Retrieved from http://www.restorativejustice.org

Priamsari, R. P. A. (2018). Seeking Justice for Children through Diversion. Law Reform Journal, 14(2).

Sari, M. A. C. M. (2013). Diversion in the Child Criminal Justice System in Indonesia. Udayana Master Law Journal, 2(1). 